\title{
EVALUATION OF EXTRUDED-TO-SIZE ELEMENTS
}

\section{(Title Unclassified)}

Prepared by:

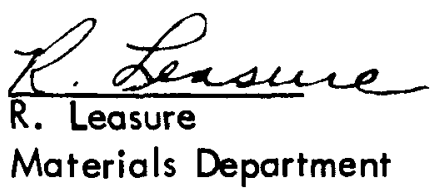

Approved by:

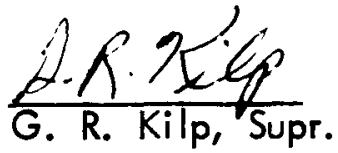

Graphite Fuel Evaluation Materials Department

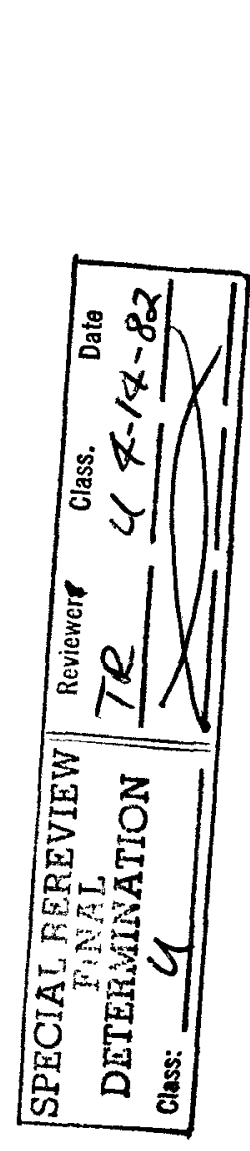

DISTRIBUTION DE JHIS DOCUMENT IS UNLIMTEO

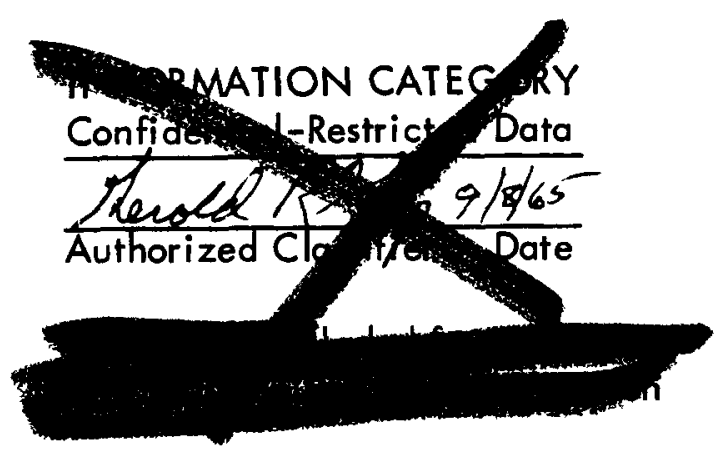

by authority of

b)

SEP $1: 1973$<smiles>CC(C)(C)c1ccccc1</smiles>

NOTICE

This report was prepared as an account of work sponsored by the United States Government. Neither the United States nor the United States Energy Research and Development Adminustration, nor any of their enployees, nor any of their contractors, subcontractors, or their employees, makes any warranty, express or implied, or assumes any legal lability or responsibility for the accuracy, completeness or usefulness of any information, apparatus, product or process disclosed, or represents that its use would not infringe privately owned rights. 


\section{DISCLAIMER}

This report was prepared as an account of work sponsored by an agency of the United States Government. Neither the United States Government nor any agency Thereof, nor any of their employees, makes any warranty, express or implied, or assumes any legal liability or responsibility for the accuracy, completeness, or usefulness of any information, apparatus, product, or process disclosed, or represents that its use would not infringe privately owned rights. Reference herein to any specific commercial product, process, or service by trade name, trademark, manufacturer, or otherwise does not necessarily constitute or imply its endorsement, recommendation, or favoring by the United States Government or any agency thereof. The views and opinions of authors expressed herein do not necessarily state or reflect those of the United States Government or any agency thereof. 


\section{DISCLAIMER}

Portions of this document may be illegible in electronic image products. Images are produced from the best available original document. 




(W) Astronuclear

WANL-TME- 1479

August, 1966

\section{INTRODUCTION}

One of the fuel element production processes being evaluated in the NRX-A5 development program is the process of extruding the bores of elements to size followed by coating in the leached or non-leached condition.

The corrosion properties of these extruded to size (ETS) elements were evaluated through a series of hydrogen corrosion tests. Additional evaluations were made by metallographic examinations, electrical resistance, and accelerated hydrolysis studies.

\section{HYDROGEN CORROSION}

A total of 11 ETS elements representing five coating batches and eight extrusion batches were hydrogen corrosion tested to evaluate their corrosion behavior. A summary of these test results along with results for similar tests of standard production elements, coated in the leached or non-leached condition, is given in Table 1.

Although the hydrogen test results show little difference in 10-minute weight losses, there is a tendency for the ETS elements to have larger 30-minute weight losses as shown in Figure 1. This additional weight loss in the ETS elements appears to be due to increased corrosion in the mid-band region as reflected in the electrical resistance curves. The resistance curves show a much wider mid-band peak for the ETS elements than is seen in elements with standard reamed bores. It should also be noted that two ETS elements failed in the mid-band region, one after 27 minutes of testing and one after 30 minutes. There were no failures in the elements with reamed bores.

\section{METALLOGRAPHY}

One of the most noticeable effects of extruding bores to size is the formation of large porous areas near the coating-graphite interface that protrude into the channels. It appears that some of these areas form when damaged fuel beads expand (due to interaction

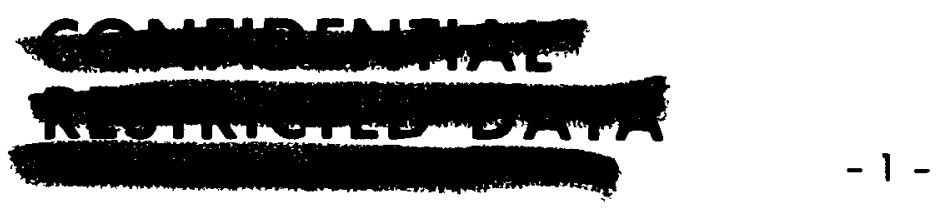


Table I - Hydrogen Testing of Extruded to Size Elements




Table I (cont.)

\begin{tabular}{|c|c|c|c|c|c|c|c|}
\hline $\begin{array}{c}\text { Coating } \\
\text { Batch }\end{array}$ & Element & Lot & Type ${ }^{(I)}$ & Test & $\begin{array}{c}\Delta W \\
\text { (gms) }\end{array}$ & $\begin{array}{c}\text { End } \\
(B A R / C A R)\end{array}$ & Comments \\
\hline$F-194$ & $99-24035$ & $X I 1$ & ETS, leached & $\begin{array}{l}\text { IB } 5+5 \\
+20\end{array}$ & $\begin{array}{r}4.0 \\
22.5\end{array}$ & $\begin{array}{c}30 / 20 \\
0 / 0\end{array}$ & Failure at $21 "$ \\
\hline & $99-23631$ & XII & STD & $\begin{array}{l}\text { IB } 5+5 \\
+20\end{array}$ & $\begin{array}{l}3.0 \\
8.5\end{array}$ & $\begin{array}{r}100 / 98 \\
80 / 75\end{array}$ & \\
\hline
\end{tabular}

(1) ETS - Bores extruded to size STD - Standard reamed bore

(2) Hydrolysis conditions - $100 \%$ humidity, $100^{\circ} \mathrm{C}, 48$ hours 

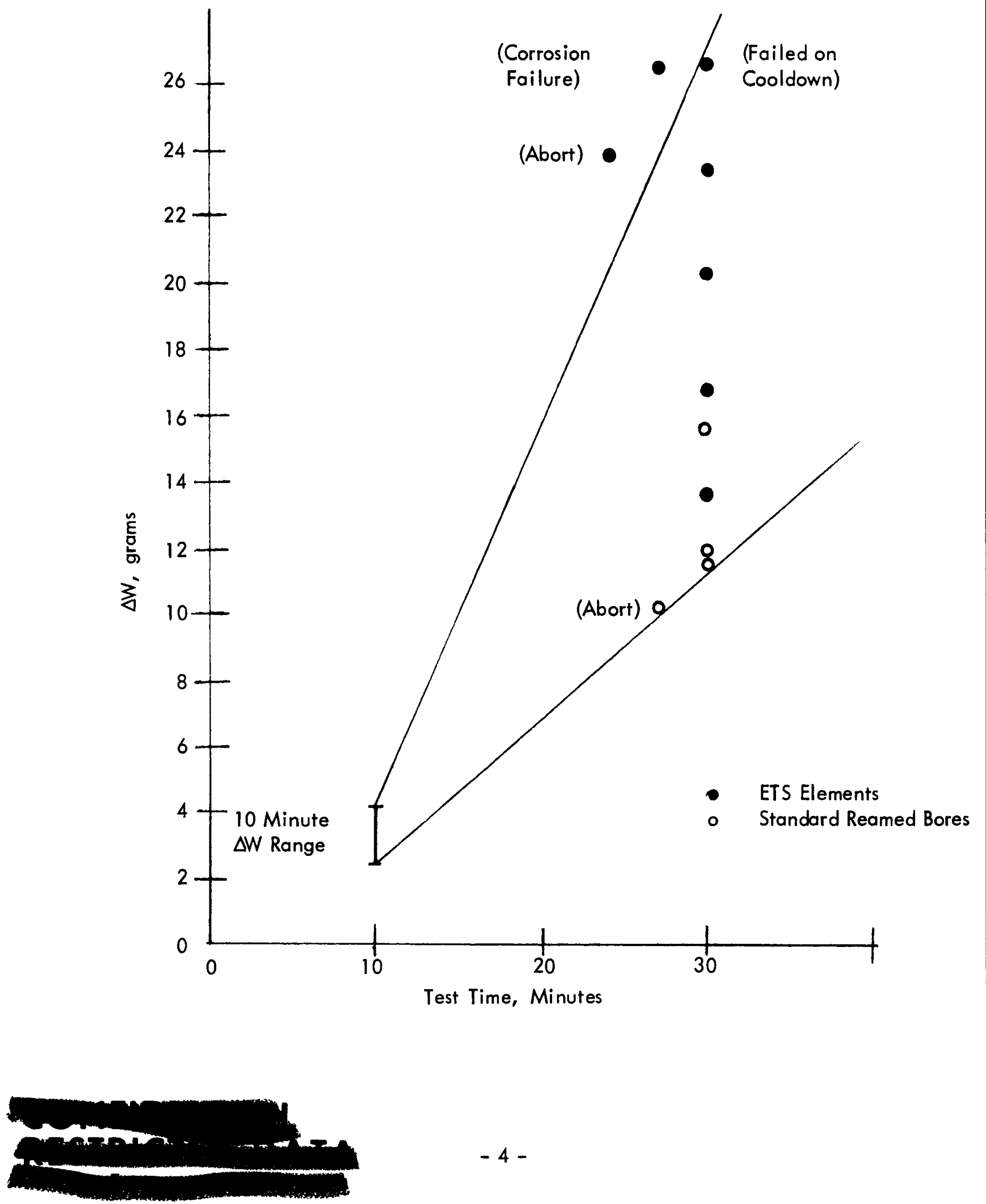


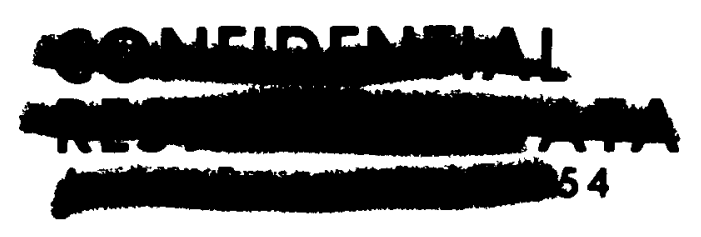

(20) Astronuclear

WANL-TME-1479

August, 1966

of exposed $U C_{2}$ with binder), forcing relatively large volumes of matrix material toward the channel. Two typical porous areas are shown in Figure 2. It should also be noted that this type of defect was observed in earlier ETS elements.

The adherence of the channel coating on the ETS elements appears to be a function of the leach. Metallography of a leached element from coating batch F-193 revealed a non-adherent coating while the non-leached element from the same batch has an adherent coating over most of the length.

Further evaluation of the ETS elements was made by accelerated aging of the fuel beads which was accomplished by exposing ETS elements to a hydrolyzing environment. Metallography of ETS leached and non-leached elements show no hydrolysis of the fuel beads after treatment at $100 \%$ relative humidity, $73^{\circ} \mathrm{C}$ for four hours. To determine if fuel bead aging has any effect on the corrosion properties of ETS elements, a leached ETS element was subjected to hydrolyzing conditions of $100 \%$ humidity, $100^{\circ} \mathrm{C}$ for 48 hours. Subsequent hydrogen testing of this element at 1B-10 conditons revealed no abnormal behavior.

\section{SUMMARY}

The limited number of corrosion tests performed on ETS leached and non-leached elements show that these elements have poorer corrosion behavior than do standard reamed elements. The standard elements had an average $\Delta W$ of 12.3 grams while the ETS elements had an average $\Delta W$ of 20.0 grams for 30 minutes of testing at $I B$ temperatures. The additional weight loss observed in the ETS elements is believed to occur in the mid-band region. In addition, two ETS elements failed due to mid-band corrosion while the elements with reamed bores had no failures.

The major effect resulting from extruding elements to size that can be seen in the microstructure of these elements is the presence of large porous areas which extend into the channels. There are indications that some of these areas may break away during hydrogen testing allowing large areas of graphite exposed during subsequent tests.

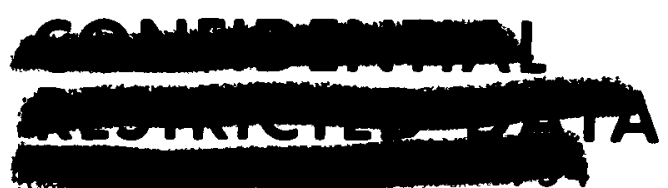




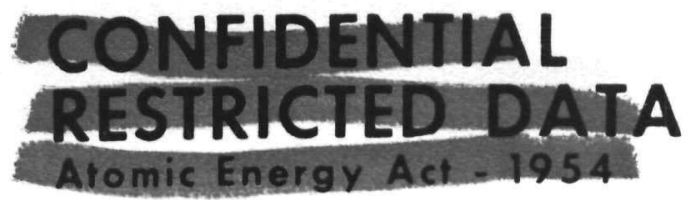

(W) Astronuclear

WANL-TME-1479

August, 1966

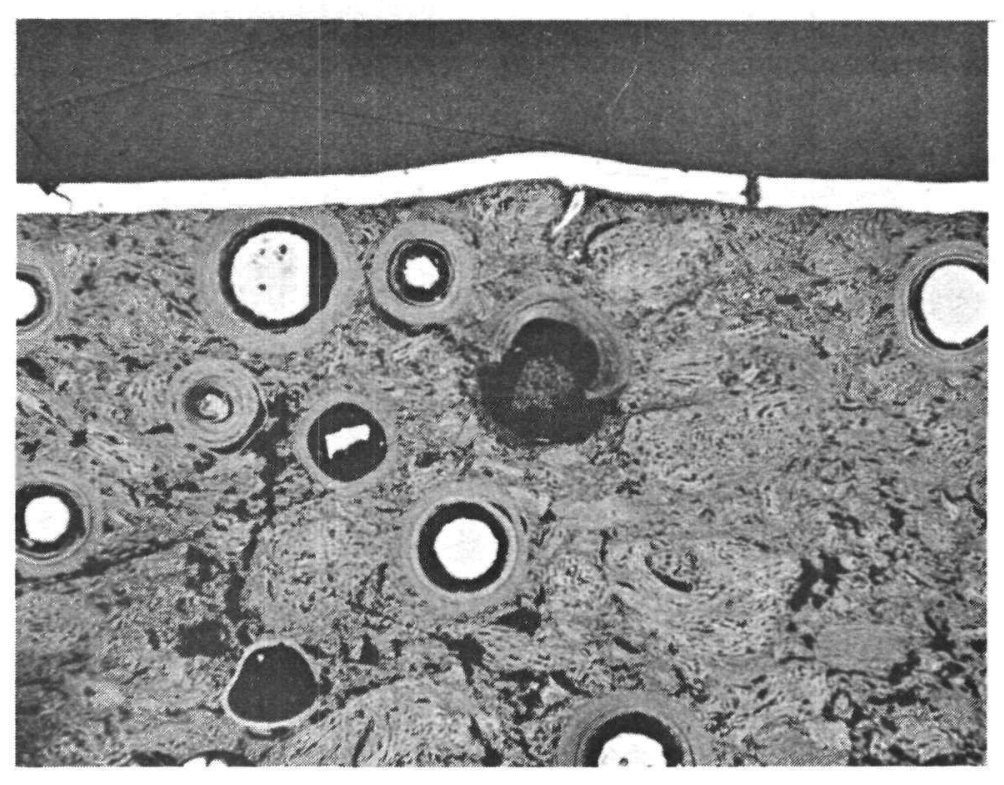

(a) Damaged Bead Causing Buckling of Matrix

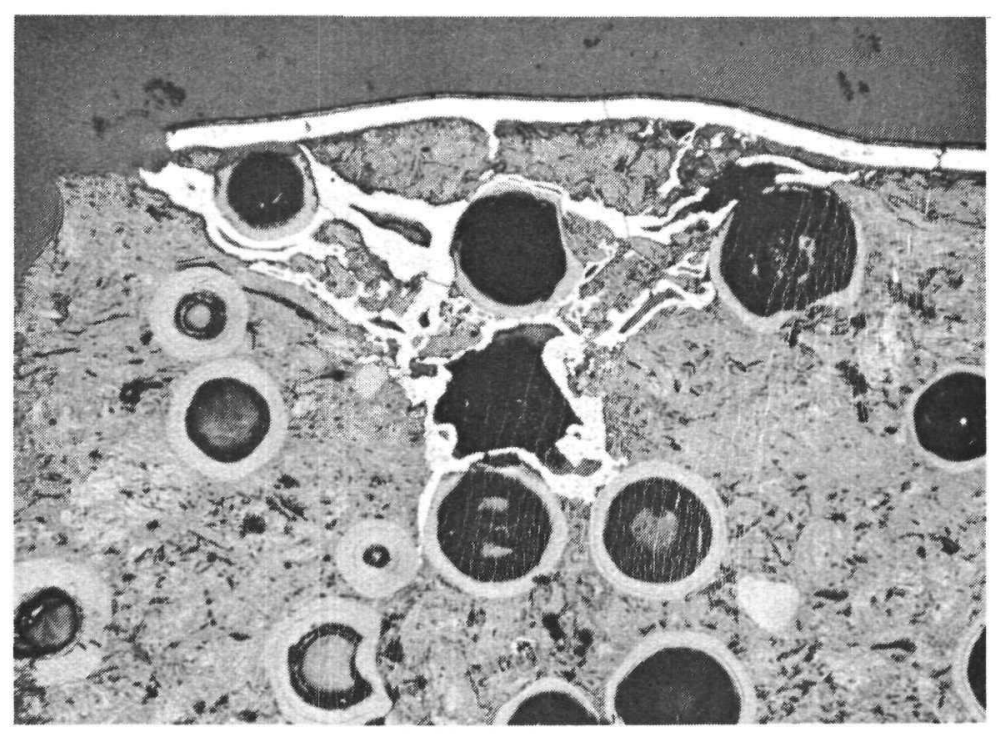

(b) Porous Area

FIGURE 2 ETS Defects 100X 